\title{
Quality Signaling through Ex-Ante Voluntary Information Disclosure in Entrepreneurial Networks: Evidence from Franchising
}

\author{
Farhad Sadeh, \\ $\mathrm{PhD}$ Candidate, Marketing \\ DeGroote School of Business \\ McMaster University \\ Hamilton, ON, Canada \\ Telephone: +1 905525 9140, Ext. 26169 \\ Email: sadehf@mcmaster.ca \\ Manish Kacker, \\ Associate Professor, Marketing, \\ DeGroote School of Business \\ McMaster University \\ Hamilton, ON, Canada \\ Telephone: +1 905525 9140, Ext. 21658 \\ Email: mkacker@mcmaster.ca
}

January 2017

We thank Josef Windsperger and Sreelata Jonnalagedda for comments on a previous version of this manuscript. This manuscript has benefited from feedback received during presentations at the 2015 EMNet conference, the 2015 ISOF conference, the 2015 Empirical and Theoretical Symposium on Marketing Strategy, the 2016 Summer AMA Conference, the 2016 ISBM Biennial Academic Conference and research seminars at the Indian Institute of Management (Bangalore) and McMaster University. We acknowledge financial support from the Franchise and Dealer Management Initiative (FDMI), McMaster University. This research was supported by the Social Sciences and Humanities Research Council of Canada. 


\begin{abstract}
This paper examines antecedents of ex-ante voluntary information disclosures for standardized contracts in entrepreneurial networks. Entrepreneurs (e.g., franchisors) may make such disclosures to prospective business partners in order to signal profitability of partnering, attract financial and managerial resources and develop their entrepreneurial networks. In practice, only a fraction of franchisors make financial performance representations (FPR), an ex-ante voluntary information disclosure to prospective franchisees. We address gaps in the signaling, voluntary information disclosure, franchising, entrepreneurship and small and medium enterprises (SME) literatures. We draw on signaling theory to develop a theoretical framework and investigate factors that influence a franchisor's disclosure decision. We evaluate hypotheses from our theoretical framework through econometric analyses of multi-sector panel data for the U.S. franchising industry. We estimate a logit model and use lagged independent variables to address our dichotomous independent variable and potential endogeneity respectively. Our results support the view that firms signal their quality through FPRs to attract potential business partners and expand their entrepreneurial networks. Beyond the extant literature, we find that a rigorous partner qualification mechanism is another driver of voluntary information disclosure in franchising. Our findings also provide empirical support for the complementary role played by multiple quality signaling mechanisms used by franchisors and yield public policy implications for franchising.
\end{abstract}

Keywords: Marketing Channels, Retailing, Agency Theory, Franchising, Contracting, Voluntary Information Disclosure, Entrepreneurship, Signaling, Financial Performance Representations, Replication Studies, Econometrics Panel Data Modeling, Logistic Regression.

JEL Classifications: L14, L26, D22, K23, M38 


\section{Introduction}

When prospective investors assess a new business opportunity, one of the first questions that come to their minds is: "How much money can I make with this opportunity?" For example, when prospective franchisees consider buying franchising rights from a franchisor, they are likely to be interested in knowing how much money an average franchisee can make in that chain. In this regard, scholarly empirical research in franchising yields two important insights the quality of the franchise business is very important for potential franchisees (e.g., Stanworth \& Kaufmann, 1996) and franchisee expectations of the future value of the franchise business are frequently not met (Grünhagen \& Dorsch, 2003). It is possible that franchisee dissatisfaction with unmet expectations can be traced to incomplete information available to prospective franchisees about the quality of the franchisor - this reflects the classical adverse selection problem in agency theory. Since there is no precise way to measure or guarantee future outcomes for new franchisees, franchisors may decide to voluntarily disclose some information about their current outlets' financial performance to signal the quality of their business concept.

The ex-ante voluntary information disclosure decision is typically faced by a variety of entrepreneurs and small and medium enterprises (SMEs) who grow by developing entrepreneurial networks and offer standardized contracts to resource owners who join these networks. Such entrepreneurial networks include not only well established business models (such as franchising) but also newer economy networks (for example, sharing economy firms such as Uber and AirBnB). In this study, we want to learn what encourages or discourages firms to make such voluntary information disclosures to prospective members of their entrepreneurial networks. Additionally, we are interested in knowing whether such a disclosure is a signal of the quality of the business concept and if so, is it a complement to (or a substitute for) other signals 
of quality. We draw on voluntary information disclosure, signaling, and franchising literatures (with an emphasis on research in the entrepreneurship and SME domains) to develop our theoretical framework and empirically evaluate our hypotheses using nine years of panel data from the U.S. franchising industry.

Voluntary disclosure of information to attract potential investors is a common practice in many financial, capital and other resource markets (Chow \& Wong-Boren, 1987; Lardon \& Deloof, 2014; Verrecchia, 1983). Information disclosures by firms have been the subject of extensive research in finance (e.g., Diamond, 1985; Keasey, Short, \& McGuinness, 1992), accounting (e.g., Chow \& Wong-Boren, 1987), law (e.g., Grossman, 1981) and marketing (e.g., Srinivasan \& Sihi, 2012). We note two important gaps in this domain, particularly in the context of entrepreneurial networks and interorganizational exchange relationships. First, there is room to enhance scholarly understanding of why some firms do not make voluntary disclosures of financial information to prospective exchange partners, since hidden information can be interpreted as a bad news (Milgrom, 1981). Second, there has been debate in franchising and other literatures over whether disclosures of financial information should be mandatory or voluntary (e.g., Dye, 1985; Hershman \& Mazero, 2008). We seek to address both these gaps in our study.

Signaling theory has been widely used to study exchange relationships characterized by the presence of information asymmetries. Spence (2002) provides multiple examples of the application of signaling theory for decreasing information asymmetry between two parties. Leland and Pyle (1977) argue that information differences are characteristic of markets and that entrepreneurs who have private information about their projects need to signal the quality of the project to resource suppliers. Backes-Gellner and Werner (2007) study how innovative 
entrepreneurs signal their quality to financial resource owners. Extant research, grounded in signaling theory, has examined how firms signal their profitability through information disclosures to attract resources needed to develop their businesses (e.g., Grossman, 1981; Milgrom, 1981). According to Michael (2003), entrepreneurs can use voluntary information disclosures to signal their profitability and attract resources from external owners of resources. Given the importance of information in contemporary business models and exchange relationships, there are key gaps in the extant signaling literature that we aim to address. First, as Kirmani and Rao (2000) note, there is a relative paucity of empirical support for quality signaling, particularly with respect to entrepreneurial networks and business-to-business exchange relationships for SMEs. Second, there are differing findings on whether multiple signals function as substitutes (Arthurs, Busenitz, Hoskisson, \& Johnson, 2009; Gallini \& Lutz, 1992; Lafontaine, 1993) or complements (Chung \& Kalnins, 2001; Filatotchev \& Bishop, 2002; Milgrom \& Roberts, 1986). Although Kirmani and Rao (2000) present a theoretical typology for the use of multiple signals, this has not been empirically tested. Thus, there is a gap in our empirical understanding of when multiple signals serve as complements and when they work as substitutes.

We seek to address the above-mentioned gaps in the signaling and voluntary information disclosures in entrepreneurial networks using the context of franchising. Since its inception in the early 20th century, franchising has had a significant impact on retailing all over the world. IHS Economics (2016) estimates 795,932 franchised business establishments in the United States in 2016 that contribute more than nine million jobs and 552 billion dollars of GDP to the US economy. Similar patterns of economic influence have emerged in other developed countries. Furthermore, Michael (2014) empirically shows how franchising lead economic development in 
developing nations. In the franchising literature, a relatively limited but growing body of research has examined franchisor signaling to prospective (e.g., Calderon-Monge \& HuertaZavala, 2014; Fadairo \& Lanchimba, 2013; Gallini \& Lutz, 1992; Lafontaine, 1993; LuciaPalacios, Bordonaba-Juste, Madanoglu, \& Alon, 2014; Michael, 2009) and extant franchisees (Kacker \& Wu, 2013). Michael (2009) examines the use of earnings claims ${ }^{1}$ by franchisors to study cost, quality and competition-based predictors of signaling.

Our study aims to contribute to the extant entrepreneurship and SME literature on signaling, voluntary information disclosure and franchising in multiple ways. First, we aim to shed light on the quality signaling role of voluntary information disclosure in a business-tobusiness context. Although research on this topic has been done in securities markets, there is room for a deeper understanding about this phenomenon in the context of interorganizational entrepreneurial networks such as franchising. We empirically investigate the extant predictors of signaling behavior in the economics literature and suggest additional antecedents of signaling. Also, we provide insights on whether multiple quality signals act as substitutes or complements. Second, we seek to shed light on the issue of information disclosure regulation. There has been debate among public policy makers and other parties about the extent to which information disclosures should be mandatory. Progress in the understanding of what motivates voluntary information disclosures facilitates decisions on what information disclosures should be mandatory. In the context of franchising, such decisions can have a substantial impact on

\footnotetext{
${ }^{1}$ An earnings claim (an example of voluntary information disclosure by franchisors) is a document that franchisors use to provide some financial information to prospective franchisees. As of July 2007, the Uniform Franchise Offering Circular (UFOC) has been renamed as FDD (Franchise Disclosure Document) and earnings claims have been renamed as Financial Performance Representation (FPR) by the Federal Trade Commission (FTC). In this paper, when we refer to previous studies, we use the term 'earnings claim' instead of FPR to be consistent with the original source.
} 
multiple stakeholders - governments, franchising-related businesses and consumers. Finally, we seek to enrich the franchising literature by responding to the call from Michael (2009) ${ }^{2}$ for testing his conclusions across multiple sectors - we use a relatively larger and newer panel dataset that covers numerous sectors. Panel data has several advantages over the cross-sectional data including but not limited to controlling for individual heterogeneity, less collinearity, more variability and efficiency, the better ability for constructing realistic behavioral hypotheses and uncovering dynamic relationships (Hsiao, 2014). Moreover, we extend his model by incorporating additional variables and alternative operationalizations of key constructs for capturing the effects of quality as well as examining the effects of partner qualification mechanisms on the provision of FPRs.

This paper is organized as follows. First, we review the literature on signaling theory, summarize the conceptual model in Michael (2009) and present our expanded theoretical model and hypotheses. This is followed by the presentation of our data, measurement, and empirical analyses that include a replication of the Michael (2009) model as well as a test of the predictions of our expanded model. We conclude with a discussion of our results and the implications of our findings.

\footnotetext{
${ }^{2}$ We replicate this study for two reasons; First, many scholars submit that replication is a necessary procedure to verify theoretical insights from empirical studies (Honig, Lampel, Siegel, \& Drnevich, 2014; Hubbard, Vetter, \& Little, 1998; Tsang \& Kwan, 1999). Second, Michael (2009) empirically tested his model using cross-sectional data from the restaurant industry. Research has shown significant differences between service and retail-type franchise chains (Barthélemy, 2008; Perrigot, 2006) and across different franchising sectors (Blair \& Lafontaine, 2005). Our multi-industry multi-year dataset helps to test whether Michael's (2009) results are supported for other industries.
} 


\section{Theoretical Background and Framework}

Since information asymmetry is at the heart of signaling theory, management researchers have applied signaling theory in a variety of research contexts characterized by it (Connelly, Certo, Ireland, \& Reutzel, 2011). Signals are information that a receiver uses to predict the behavior of the sender. Thus, signals should transmit external information easily and should contain the quality and value of the signaled object (Lucia-Palacios et al., 2014). A good signal should be observable, irreversible, governed, credible and costly to imitate (Certo, Daily, \& Dalton, 2001; Janney \& Folta, 2006; Lee, 2001).

In the franchising literature, research has been done on signaling by franchisors. In their analytical model, Gallini and Lutz (1992) assume that the franchisor has better information about profitability of the business than the franchisee - so, the information asymmetry problem can be solved by the more informed party (the franchisor) claiming an observable stake in the product's profitability. They relate their model to the analysis, by Leland and Pyle (1977), of profitability signals sent by entrepreneurs to attract potential shareholder investment in their project. Lafontaine (1993) offers the first empirical assessment of whether franchisors signal their quality by directly operating outlets and through contractual terms such as the royalty rate and franchise fee. Although she did not find empirical support for the use of franchise contract terms as a signal of profitability, Kacker, Dant, Emerson, and Coughlan (2016) and Shane, Shankar, and Aravindakshan (2006) subsequently find support for some previous signaling propositions. The latter claims that the lack of support for the signaling explanation in Lafontaine (1993) is a result of measurement error. Calderon-Monge and Huerta-Zavala (2014) study the relationship between certain signals of quality from franchisors and the choice of a brand by prospective franchisees. Lucia-Palacios et al. (2014) is another contemporary study that demonstrates the 
effect of supporting services and contractual arrangement (as signals to attract prospective franchisees) on chain growth.

Michael (2009) indicates that many entrepreneurs use franchising to attract resources (e.g., financial and human resources, business location and physical assets) and resolve the agency problem between the local manager and the business owner. He investigates use of signaling by entrepreneurs in the franchising context, by empirically examining franchisor use of earnings claims (now known as FPRs). Franchisors have an option to provide an FPR as a part of the Franchise Disclosure Document (FDD). Therefore, an FPR - a piece of information provided by the franchisor for disclosing an estimate of income - is a good example of voluntary information disclosure. In an FPR, a franchisor reports average sales and expenses and some other financial information, to enable a potential franchisee to estimate expected returns from her investment (Michael, 2009). Although the provision of an FPR is at the discretion of franchisors, they are forced by law to provide truthful information if they decided to provide it. Thus, an FPR is a source of credible information and has been used in a number of other studies (e.g., Clarkin \& Rosa, 2005; Kaufmann, 1995; Michael, 1999).

To investigate franchisor behavior in disclosing information through FPR, we develop our model based on signaling theory. We build our model around quality signaling and partner qualification (for assessing the quality of prospective franchisees) as key predictors, while controlling for the effect of other important factors.

\subsection{Signaling Quality}

The relationship between quality and signaling has been established in information economics literature. Spence's (1973) seminal theoretical work shows how a job market 
applicant signals her quality (through higher education) to a prospective employer. Milgrom (1981) predicts that profitable firms that have good news are more likely to publish their information. Connelly et al. (2011) review more recent examples in the literature to illustrate how underlying quality is signaled by disseminating information about different dimensions of quality through a variety of means such as the ownership of stakes, display of resources and the inclusion of prestigious directors on the board. A franchisor sells franchise rights to franchisees, so the quality of its franchise concept impacts profitability for franchisees. Therefore, we argue that franchisors provide an FPR to signal profitability of their business concept to potential franchisees and, hence, we expect a higher likelihood of making FPR for the franchisors with a higher quality of the business. Since there is no global, precise and readily available measure of franchisor quality, we search for other signals of quality that have been established in the extant literature to see whether there is an association between them and voluntary information disclosure in the form of FPRs.

Ongoing Fees: The relationship between price and quality and the use of price as a signal of unknown quality have been the subject of many studies in the economics literature (e.g., Bagwell \& Riordan, 1991; Milgrom \& Roberts, 1986; Nelson, 1970). In the franchising literature, Gallini and Lutz (1992) proposed royalty rates as a signal of franchisor quality for franchisees. According to Kacker et al. (2016), these ongoing fees facilitate a franchisor's provision of continuing support and advertising services that build and promote the chain's brand. Brand equity and a franchisor's ongoing efforts to promote the brand name are important indicators used by prospective franchisees for choosing a franchisor (Guilloux, Gauzente, Kalika, \& Dubost, 2004). There is considerable support in the literature for the view that ongoing fees are positively related to the franchisees' business profitability and that they are indicators of 
franchisor's expenditure for product differentiation and future level of services provision (Kacker et al., 2016; Lafontaine, 1992; Michael, 1999, 2009). ${ }^{3}$ In his property rights view of franchising fee structure, Windsperger (2001) notes that franchisors with higher intangible assets, such as brand name and know-how, request higher royalties as residual income rights. Given these links between ongoing fees and franchisor quality and between franchisor quality and the likelihood of a franchisor making an FPR, we posit:

H1a: The higher the ongoing fees charged by a franchisor, the higher the likelihood that the franchisor will make an FPR.

This hypothesis (as well as a number of subsequent ones) implies a complementary and mutually reinforcing relationship among signals of quality. Thus, the quality signaling effect of ongoing fees charged by a franchisor can be direct (Gallini \& Lutz, 1992) as well as indirect, in terms of influencing the likelihood of other signals such as FPR being made (Michael, 2009). This is consistent with other signaling models (Milgrom \& Roberts, 1986) and empirical studies (Chung \& Kalnins, 2001; Filatotchev \& Bishop, 2002) that have incorporated multiple signals of quality.

If we assume that franchisors duplicate their message by using multiple signals, it is possible that these different signaling mechanisms can serve as substitutes. A number of researchers have considered multiple signals as substitutes (e.g., Arthurs et al., 2009; Gallini \&

\footnotetext{
${ }^{3}$ Price (2000) examines the effect of contractual payments on the likelihood of making an earnings claim. She reports a positive relationship between contractual payments (including the royalty rate) made by franchisees to the franchisor and the franchisor's likelihood of making an earnings claim. It should be noted that she views contractual payments (including ongoing fees) as a measure of the franchisee's investment risk rather than as an indicator of franchisor quality. This perspective may not fully recognize the initial and ongoing services (provided by the franchisor to franchisees) that correspond with initial and ongoing contractual payments.
} 
Lutz, 1992; Lafontaine, 1993). Using this rationale, we develop a competing hypothesis ${ }^{4}$ and posit that a franchisor who signals its quality by charging high ongoing fees does not need to signal quality through the provision of an FPR. Therefore,

H1b: The higher the ongoing fees charged by a franchisor, the lower the likelihood that the franchisor will make an FPR.

Commitment to Industry Standards: Akerlof (1970) argues that licensing and certification reduce uncertainty around quality. In economics and strategic management, there is a large body of literature that supports signaling quality through third-party certification and commitment to standards. For example, Terlaak (2007) examines 'certified management standards' as a potential signal of quality, since they are less costly to acquire for firms with higher quality standards. According to Montiel, Husted, and Christmann (2012), attaining such certifications are costly and act as a quality signal; however implementing these standards without the third-party certification are not considered as signals since they are costly to observe. Therefore, considering commitment to industry standards as a quality dimension, we posit that:

H2a: A franchisor's commitment to industry standards is positively associated with the likelihood of the franchisor providing an FPR.

Again, assuming signals are substitutes, we can posit a competing hypothesis that if franchisors can signal their quality through Commitment to Industry Standards, they should be less likely to provide an FPR. Support for this competing hypothesis is also provided by Price

\footnotetext{
${ }^{4}$ This approach of using competing hypotheses has been used in extant research in franchising (e.g., Hendrikse, Hippmann, \& Windsperger, 2015) and entrepreneurship (e.g., Strotmann, 2007) and enhances the objectivity and rigor of theory testing (Armstrong, Brodie, \& Parsons, 2001). It has its roots in the 'Strong Inference' model of inductive-reasoning based scientific inquiry (Platt, 1964) and recognizes the limitations of scientific inquiry grounded in single hypotheses (Chamberlin, 1897).
} 
(2000), who posits that franchisors with better reputations are less likely to voluntarily disclose their earnings information.

$\mathrm{H} 2 \mathrm{~b}:$ A franchisor's commitment to industry standards is negatively associated with the likelihood of the franchisor providing an FPR

Complexity: Complexity of the business concept is defined by Shane (1998) as the number of services provided by the franchisor to support the chain members - these include services such as (but not limited to) central data processing, central purchasing, and field training. Kacker et al. (2016) posit that these supporting services can differentiate the business concept, enhance brand equity and serve as a quality signal of the business concept. Kaufmann and Dant (2001) conclude that franchisors who invest in promoting their brand and providing high levels of training to support their brand also offer high levels of ongoing support. Therefore, they considered the amount of training by franchisor as an indicator of quality. Some other researchers have also viewed a franchisor's services and training as an indicator or cause of quality (Justis \& Chan, 1991; Luangsuvimol \& Kleiner, 2004). Thus, we posit that:

H3a: The greater the complexity of a franchisor's franchise concept, the higher the likelihood of the franchisor making an FPR.

Again, we present a competing hypothesis, based on the notion that signals of quality act as substitutes.

H3b: The greater the complexity of a franchisor's franchise concept, the lower the likelihood of the franchisor making an FPR.

Concept Development Time: According to Aldrich and Auster (1986), new and younger firms are faced with high failure risk that diminishes as they spend time on organizational 
learning and developing their organizational processes and routines. Kacker et al. (2016) posit that franchisors who spent more time in developing their business concepts before commencing franchising are more likely to create unique and strong franchise concepts and be in a better position to fully dedicate their resources to monitoring franchisees and safeguarding the brand once they start franchising. Thus, they view concept development time as a signal of franchisor quality. Lafontaine (1993) views the number of years a franchisor was in business before commencing franchising as a measure of reputation. She notes that years of operation prior to franchising - years that franchisors have spent in developing their business concepts - is evidence of their success and the value that franchisor brings to the business by itself. Therefore:

H4a: The longer a franchisor's concept development time, the higher the likelihood of the franchisor providing an FPR.

Continuing with the rationale of substitute signals advanced in previous sections, we also posit the following competing hypothesis:

H4b: The longer a franchisor's concept development time, the lower the likelihood of the franchisor providing an FPR.

Fraction of Ownership: Leland and Pyle (1977) model a capital market where entrepreneurs search for financing for their project with unknown quality. They claim that entrepreneurs signal favorability of a project to market through their fraction of ownership of it. Grounded in transaction cost economics, Hsieh, Lazzarini, Nickerson, and Laurini (2010) show that ownership of downstream processes facilitates controlling and monitoring and this that to better process quality (in terms of lower variability and higher reliability). 
In the franchising literature, Gallini and Lutz (1992) show how company ownership acts as a way of convincing potential franchisees about the profitability of the business. Sorenson and Sorensen (2001) empirically show that franchisor-owned units contribute to chain growth and stability more than franchised units do. Based on the theoretical rationale of underinvestment in shared assets because of potential opportunism, free riding, and conflict, Michael (1999) shows that franchising (measured as the percent of franchised outlet in a chain) is negatively associated with investment in advertising and this hurts shared assets such as the chain's brand value. Michael (2000) empirically shows the effects of ownership on quality for hotel and restaurant industry. He argues that, as a residual claimant of the business, a franchisee's individual effort on quality compensates the whole chain and hence the franchisee does not gain the entire benefit of her efforts. This is an externality that encourages free-riding by other members of the chain, adversely impacting quality. Building on these theoretical rationales, Michael (2009) argues that franchisors are more likely to keep ownership of outlets when they are more profitable. Thus, we posit:

H5a: The higher a franchisor's fraction of ownership, the higher the likelihood of the franchisor providing an FPR.

There is a counter argument, in terms of viewing an FPR as a substitutable signal of quality. This leads to the following competing hypothesis:

H5b: The higher a franchisor's fraction of ownership, the lower the likelihood of the franchisor providing an FPR. 


\subsection{Partner qualification}

Signaling profitability of the business through information disclosure enlarges the pool of both low and high quality applicants. Although such disclosures alleviate the adverse selection problem for the partner (Mishra, Heide, \& Cort, 1998), it increases the same risk for the discloser because it attracts many low quality applicants. When a franchisor faces an adverse selection problem in evaluating potential franchisees who want to join the franchise network, she can overcome this problem through rigorous qualification requirements for new franchisees (Kacker et al., 2016). However, the use of such requirements reduces the pool of prospective franchisees and creates a greater need for the franchisor to compensate them for investment risk and remain attractive compared to other opportunities available to them. Seshadri (2002) defines the favorability of external agency as a latent variable and hypothesizes that it is positively related to the minimum-net worth required of the potential franchisee. He argues that a high level of required net worth decreases the number of qualified applicants. In order to attract these qualified applicants, a franchisor may need to make an FPR to mitigate that negative effect and increase the attractiveness of the franchising opportunity. Kacker et al. (2016) posit that the initial fixed fees paid by franchisees to the franchisor are also a tool to alleviate the adverse selection problem posed by new franchisees. High initial fixed fees serve as a mechanism for screening and qualifying potential franchisees. By using them, a franchisor can decrease the likelihood of franchisee opportunism and ease the adverse selection problem posed by prospective franchisees (Stump \& Heide, 1996). Price (2000) specifically considers such fees as measures of the franchisee's investment risk. Therefore, we posit:

H6: $\quad$ The greater the rigor of a franchisor's qualification requirements, the higher the likelihood of the franchisor providing an FPR. 


\section{Empirical Analyses}

\subsection{Data}

We test our hypotheses using secondary, unbalanced panel data from Bond's Franchise Guides from 2001 to 2009. Bond's Franchise Guides have been publishing annually from 1985 to 2009 , with some exceptions. This is a survey-based database of more than 1000 franchise chains in the U.S. and Canada and has been widely used in extant franchising research (Antia, Zheng, \& Frazier, 2013; Gillis, Combs, \& Ketchen, 2014; Kacker et al., 2016; Lafontaine \& Blair, 2009; Lafontaine \& Shaw, 1998, 2005). We excluded Canadian franchisors (constituting about 10 percent of the data) from the dataset because our assumptions about FPR are based on U.S. regulations. The sample is an unbalanced panel of 8,152 observations from 1,639 franchisors of 44 industries over 9 years. Average number of observations per franchisor is 4.97 . Table 1 contains details of our variables and constructs' operationalization.

Insert Table 1 about here

\subsection{Dependent Variable}

The dependent variable in our framework is whether the franchisor provides a FPR. Therefore, we operationalize it as a binary dichotomous variable with a value of one when a franchisor provides an FPR and zero otherwise. Although there may be some variations in the content of FPRs across franchisors, investigating them is beyond the scope of this study. We believe this operationalization does not hurt our conclusions, since our goal in this study is finding what makes franchisors decide to provide or not provide an FPR. 


\subsection{Independent Variables}

\subsubsection{Quality}

Since we do not have access to a direct measure of quality, we hypothesized a relationship between dimensions of the quality and the dependent variable. In this section, we explain how those dimensions are measured.

Ongoing fees: A franchisee usually pays ongoing fees (such as royalties and advertising fees) to a franchisor. To capture all ongoing fees, we operationalize them through the summation of the royalty rate and the advertising fee.

Commitment to Industry Standards: Lafontaine (1993) notes that, in addition to royalty rates and franchise fees, there may be other ways for franchisors to signal their quality. She mentions International Franchise Association (IFA) membership as an indicator of franchise chain quality because it entails respecting certain criteria and a code of ethics. Sen (1993) suggests that IFA membership decreases chain-specific risks. The IFA's code of ethics and its training and supporting programs increase the quality of its members. Hence, we operationalize the franchisor's commitment to industry standards through their IFA membership status. This operationalization takes the form of a binary variable, with a value of one for IFA members and zero otherwise.

Complexity: We measure the complexity of the business by counting the number of supporting services provided by the franchisor to franchisees (Kacker et al., 2016; Shane, 1998).

Concept Development Time: Many franchisors start their chains by initially operating owned units and subsequently opening franchised units. Lafontaine and Shaw (1998) find that business experience before franchising is a primary factor affecting franchisor survival and 
growth. They argue that years of operation prior to franchising - years that franchisors have spent on developing their business concepts - is evidence of their success and the value that the franchisor brings to the business by itself. In a later study (Lafontaine \& Shaw, 2005), they used the number of years in business that the franchisors spent on developing their system before they began to franchise as a measure of the value of brand. Consistent with the extant literature, we measure this construct using the number of years between initiation of the business and the first franchisee sale.

Fraction of Ownership: Franchisors often simultaneously manage some outlets by themselves and sell ownership rights for other outlets to franchisees. We measure this variable as the proportion of all outlets that are owned and operated by the franchisor.

\subsubsection{Partner Qualification}

Consistent with the rationale that is presented for H6, we measure the rigor of a franchisor's qualification requirements through the minimum-net worth required of the potential franchisee and the amount of the initial franchise fee.

\subsection{Control Variables}

In modeling the impact of quality on signaling, it is necessary to control for the effect of other potential drivers (Rostamkalaei \& Freel, 2016). Signaling theory suggests cost and competition as other factors that may influence the signaling decision (e.g., Cheong \& Kim, 2004; Connelly et al., 2011; Grossman, 1981; Michael, 2009; Milgrom, 1981). Since we focus on quality signaling through voluntary information disclosure, we control for cost and competition. Cost of Signal consists of ex-ante costs of gathering and processing the information to be disclosed, ex-post costs of potential litigations related to the FPR. We measure these costs using 
the size of the chain - this is a proxy for capturing ex-ante costs (precision of the information) and ex-post costs (number of potential litigants, likelihood of leakage of proprietary information as well as access to resources for deterring and fighting potential litigation and leakage of proprietary information). Competition is defined here between franchisors in the same industry to attract a potential franchisee who has chosen an industry sector (Michael, 2009; Stanworth \& Kaufmann, 1996). We measure competition in two ways - market share and two-firmconcentration ratio 5 .

Multi-unit Franchising. Some franchisors permit existing franchisees to add additional units and/or pursue conversion franchising. These franchisees typically have more information about the profitability of new franchised units than prospective franchisees that are new to the chain. Bagwell and Riordan (1991) demonstrate a decline in the use of high prices as signals of quality when the number of informed consumers increases and the degree of information asymmetry decreases. With the same reasoning, it can be argued that when franchisors allow for additional units and/or conversion there will be a higher proportion of informed customers in their market. In such a situation, franchisors may have a relatively weaker incentive to provide FPR. Therefore, we control for this effect in our model using two dummy variables.

Institutional Isomorphism is another factor that impacts the disclosure decision. Michael (2009) hypothesizes that franchisors claim when their industry competitors or a highly visible competitor chooses to claim. Thus, we account for this effect through two control

\footnotetext{
${ }^{5}$ We used this measure since it is suggested as a better measure by Golan, Judge, \& Perloff (1996) and Kwoka (1979) and allows us to be consistent with Michael (2009). To assess the robustness of our model, we also estimated it using the more common four-firm-concentration measure. Our estimation results revealed that the empirical support for our hypotheses was not affected by this change.
} 
measures - the number of competitors who make FPRs and a dummy variable with value of one if the market leader makes FPR and zero otherwise.

We also control for the effect of Environmental Uncertainty since it impacts the cost of signaling ${ }^{6}$. Consistent with existing empirical work in franchising (e.g., Hendrikse \& Windsperger, 2011, López-Bayón \& González-Díaz, 2010), we use contract duration to measure this construct. Extant research has shown that there is a relationship between contract duration and environmental uncertainty. However, there are conflicting rationales and evidence about whether the relationship is negative (Crocker \& Masten, 1988; López-Bayón \& González-Díaz, 2010) or positive (Hendrikse \& Windsperger, 2011). Since this is a control variable in our model, we do not hypothesize any direction for its effect on the voluntary information disclosure decision.

\subsection{Methodology}

Before testing our model and hypotheses ${ }^{7}$, we replicate as much of Michael (2009) model as we can using our multi-sector panel dataset. This enables us to assess the robustness of his findings, which were based on empirical analyses of cross-sectional data from one sector (restaurants). In the replication portion of our empirical analyses, we use similar operationalizations to facilitate comparisons with the original work ${ }^{8}$. There are two exceptions. First, we did not have access to data on the percent of franchisees who failed, so we did not test the corresponding hypothesis. Second, instead of using final product sales data, we operationalize market share in a different manner. This is influenced by the availability of data as

\footnotetext{
${ }^{6}$ We thank an anonymous reviewer for this insight.

${ }^{7}$ Note that some of our hypotheses (H1a, H5a, H5b) are similar to hypotheses first developed and presented by Michael (2009).

${ }^{8}$ Michael (2009) measured cost of signal and ongoing fees with the number of owned units and royalty rate respectively.
} 
well as the view that the market here involves the sale of franchising rights to operate retail units. Thus, we follow Brickley, Misra, and Van Horn (2006) and calculate market share for a franchise chain as the number of outlets of the chain divided by total number of outlets in the industry. Table 2 and 3 contains descriptive statistics, correlations and estimation results for the replication, using the same Probit regression method and our multi-sector panel dataset. Our results are largely consistent with those in the original study and serve as an indicator of the robustness of Michael's (2009) findings.

\section{Insert Table 2 and Table 3 about here}

We enhance the model in the following manner. First, we focus on the quality signaling rationale and add new dimensions of quality to the model (i.e., Commitment to Industry Standard, Complexity, and Concept Development Time). Second, we introduce "partner qualification" as a new antecedent. Third, we control for many other predictors of signaling behavior to disentangle the impact of quality factors on the signaling decision. Fourth, we use alternate and, in our view, more accurate operationalization for some of the focal constructs and control variables (e.g., ongoing fees, cost). Descriptive statistics and correlations for the expanded model are reported in Tables 4 and 5.

\section{Insert Tables 4 and 5 about here}

We test the predictions of our expanded model using the multi-sector, panel data set. In accordance with prior panel data analyses (Kosová \& Lafontaine, 2010; Lafontaine \& Shaw, 1999; Shane et al., 2006), we use fixed effects estimation to control for fixed effects of years and industry categories which is controlled in other franchising studies (e.g., Bates, 1995). As discussed earlier, our binary dependent variable prevents us from using OLS. Additionally, we 
cannot use Probit estimation because it is biased for fixed effects estimation (Baltagi, 2008).

Therefore we estimate our model using a Logit model. We considered royalty rate, advertising fee, franchise fee and IFA membership as endogenous variables because it can be argued that franchisors may make decisions about providing an FPR and those strategies simultaneously. Consistent with extant franchising literature (e.g., Combs, Michael, \& Castrogiovanni, 2009; Gonzalez-Diaz \& Solis-Rodriguez, 2012; Kacker et al., 2016; Lafontaine, 1992; Mitsuhashi, Shane, \& Sine, 2008; Shane et al., 2006), we use lagged independent variables to account for endogeneity. Although these variables remain constant for many franchisors over several years, they are frequent strategic choices of the franchisor. In other words, a franchisor has the option to change contract characteristics every year; however, they may strategically decide to keep them unchanged. Therefore, the lagged variable is assumed exogenous since it is a decision that has been made in the last period.

Equation 1 shows our econometric model where $\mathrm{i}$ is the franchise system, $\mathrm{t}$ is the year, FPR is the binary variable for the provision of FPR, $\mathrm{X}_{\mathrm{it}}$ is the matrix of exogenous variables, $\mathrm{Z}_{\mathrm{it}-1}$ is the matrix of lag of endogenous variables, YEAR and CAT are sets of dummy variables for $\mathrm{j}$ years and $n$ categories.

$$
\text { Logit FPR } R_{i t}=\beta_{0}+\beta_{1} X_{i t}+\beta_{2} Z_{i t-1}+\sum_{J=s}^{E} \gamma_{j} Y E A R_{j i t}+\sum_{1}^{N} \delta_{n} C A T_{n i t}+\alpha_{i}+\varepsilon_{i t}
$$

\section{Results}

As illustrated by Table 6, the estimation results for our expanded model (Model 1) reveal that the model as a whole is significant at conventional levels. With respect to individual hypotheses, we observe that all focal quality hypotheses (H1a, H2a, H3a, H4a and H5a) are supported. There is also partial support for H6 (partner qualification). We also note that the 
competing hypotheses (H1b, H2b, H3b, H4b and H5b) are not supported. Although our results support the signaling impact of ownership, Lafontaine and Shaw (2005) show that proportion of owned units declines in early stages of franchising. They find that this percentage remains stable for franchisors with more than 7 years of experience and at least 15 outlets. One implication of this finding is that fraction of ownership is an appropriate measure of quality only for franchise chains that have reached a threshold level of experience ( 7 years) and size (15 outlets).

Therefore, we also estimated our model with data for this part of the sample only (Model 2 in Table 6). ${ }^{9}$ When comparing the results for Model 2 to those for Model 1, we observe that there is no change in the significance of the variables, that there are larger coefficients for some variables and also a better overall model fit (Pseudo $\mathrm{R}^{2}$ ).

\section{Insert Table 6 about here}

Our results shed new light on antecedents of information disclosure and quality signaling by franchisors. All coefficients of quality signals (H1a, H2a, H3a, H4a, H5a) are positive and significant - this indicates clear support for the quality signaling rationale. Furthermore, these results suggest complementarity in the use of multiple signals - franchisors that signal their quality through other mechanisms are more likely to also signal their quality with FPRs.

We hypothesized (H6) that franchisors use FPRs to diminish the negative effect of rigorous partner qualification standards that franchisors use to alleviate the adverse selection problem they face. In the empirical results, there is support for minimum net worth but not for franchise fee. Considering the relatively high correlation between the two variables and lower

\footnotetext{
${ }^{9}$ We thank an anonymous reviewer for this suggestion.
} 
variation in the franchise fee, it can be argued that minimum net worth has more ability to show the effects of rigorous partner qualification standards.

Control variables. The significant effect of cost of signaling is consistent with signaling and franchising literatures and supports the view that high cost is a barrier to signaling. No measures of competition have a significant effect. There is significant negative coefficient for addition of outlets but not for conversion - this suggests that franchisors who allow for addition of outlets by their current franchisees have relatively lower incentives to disclose information through FPR. The significant effect of institutional isomorphism suggests that some signals result from imitative behavior rather than rational economic decision making. We do not observe a significant effect for environmental uncertainty.

\subsection{Complementarity of Quality Signals}

Our empirical analyses revealed positive effects of different quality constructs on the voluntary disclosure decision. To advance our understanding of using multiple signals, we categorized the six signals in our model using the Kirmani and Rao (2000) signal classification typology (Table 7). Kirmani and Rao (2000) posit that when signals belong to different categories, they work as complements.

\section{Insert Table 7 about here}

For the classification of quality signals in our study, we prepared an explanation of the signals as well as a classification procedure and asked five researchers (familiar with franchising literature and signaling theory) to classify the signals. We calculated inter-rater reliability of the results as Krippendorff's alpha of 0.83, based on Hayes and Krippendorff (2007). FPR classification was the only inconsistent result and resolved after discussion between raters and 
the researchers. Considering the high ex-post costs associated with FPRs, it was classified as default-contingent signal. All other signals were classified as default-independent (except ongoing fees and ownership that are classified as revenue-risking default-contingent signals). Although an FPR is in the same primary type as ongoing fees, it is different in that it is a costrisking (rather than a revenue-risking) default-contingent signal. Thus, the signals are spread across different types and there is no other revenue-risking, default-contingent signal (in addition to an FPR). Consequently, the other quality signals in our framework are complementary to FPR.

\section{Discussion and Implications}

\subsection{Discussion}

This study is aimed to explain voluntary financial information disclosure as a signal of quality and elaborate on its relationship with other signals of quality. While much of the extant entrepreneurial signaling literature is focused on personal characteristics of entrepreneurs, board members or underwriters as signals of quality (e.g., Asoni \& Sanandaji, 2016; Backes-Gellner \& Werner, 2007; Williams, Duncan, \& Ginter, 2010), we concentrate on organizational strategies and attributes that can be used as signal of quality by entrepreneurs who want to develop their businesses through franchising. In contrast to Michael (2009), we find strong support for the quality signaling rationale for making an FPR when we use additional measures of quality (Commitment to Industry Standards, Complexity and Concept Development Time) along with an enhanced measure of ongoing fees. Our finding that higher quality franchisors are more likely to make an FPR also supports the idea of multiple quality signals working as complements rather than substitutes. Our analyses also reflect Kirmani and Rao’s (2000) suggestion that signals from different categories work in a complementary manner. To our knowledge, this analysis 
provides the first empirical valuation of Kirmani and Rao's position on the complementarity of signals and, in doing so, offers a possible mechanism for reconciling divergent results in extant research - some empirical studies find signals functioning as as substitutes (e.g.,Arthurs et al., 2009; Lafontaine, 1993) while others find them working as complements (Chung \& Kalnins, 2001; Filatotchev \& Bishop, 2002).

Our results also provide some support for the relationship between partner qualification processes and provision of FPR. This not only reflects agency theory prescriptions for franchisor alleviation of the adverse selection problem posed by prospective franchisees but also is consistent with the transaction cost theory literature about partner screening and selection process. According to Wathne and Heide (2000), increasing the rigor of the selection process by imposing selection costs on partner can be a good strategy for managing opportunism. Although high qualification standards shrink the pool of franchisee applicants, signaling profitability of business through FPR attracts high quality franchisees.

\subsection{Implications}

This study has theoretical, managerial and policy implications. We make contributions to scholarly research on signaling, voluntary information disclosure, franchising, entrepreneurship and SMEs, provide managerial implications for franchising practitioners and offer public policy insights on the issue of voluntary versus mandatory information disclosure in franchising.

We contribute to signaling theory in multiple ways. First, whereas much of the empirical research on entrepreneurships looks at quality signals in securities markets and the issue of attracting investors to a firm's stock, this study considers quality signaling to prospective entrepreneurial network partners in franchising. In addition to differences between the two 
contexts in terms of forms, risks, and benefits, the ability to study quality signals over time as a longitudinal process (instead of one shot IPO events) is an important and unique feature of our research context (franchising). Second, observing multiple signals over several years enables us to assess signal intensity and consistency (Gao, Darroch, Mather, \& MacGregor, 2008; Riley, 1975). Our results show a positive correlation between the use of FPR and five other quality signals. Also, our data reveals relative stability in the use of signals over time (70-90 percent) for most of the signals and 92 percent stability in use of FPR over the nine years of the study. These results suggest that it is feasible to, in a franchising context, empirically assess signaling theory views about how intensity and consistency of signals can beneficially impact performance. Third, this study attempts to reconcile potentially conflicting views on whether signals are potential substitutes or complements. Our findings support the latter view and are consistent with economic models that entail the use of multiple signals (Milgrom \& Roberts, 1986). According to Kirmani and Rao (2000), empirical studies that incorporate multiple signals are sparse. Using their theoretical model, we classified our signals to understand and explain complementarity between franchisor use of an FPR and other signals of franchisor quality. This is also consistent with the idea that the effectiveness of signals depends on their consistency, which is reflected by consistent communication through multiple signals that capture different dimensions (Gao et al., 2008; Riley, 1975).

This study contributes to the franchising and voluntary information disclosure literatures in several ways. First, it answers Michael's (2009) call for testing his conclusions (about voluntary information disclosure in franchising) across multiple industries - we replicate his model using a larger and newer multi-industry panel data. He found support for the effect of cost of signal but not for the quality and competition and our findings from the replication of his 
model are consistent with his original findings and provide evidence of their robustness. Second, we develop an enhanced model with amended operationalizations for some of the variables in Michael (2009) as well as additional dimensions of quality and new antecedents ${ }^{10}$. Third, we address potential causality and endogeneity problems by using panel data and lagged predictors. A key new finding, resulting from our enhanced model, data and estimation approach, is the emergence of clear support for the quality signaling rationale for the provision of an FPR by a franchisor.

Our results have some implications for franchising practitioners. Our empirical findings in support of our quality signaling hypotheses suggest that high quality franchisors should provide FPR to signal their profitability to prospective franchisees. The provision of FPRs is more important for high quality franchisors with rigorous screening and qualification requirements (e.g., minimum net worth) for prospective franchisees. In a broader context, this study supports quality signaling by entrepreneurs and SMEs who need to attract business partners for investment in their entrepreneurial networks. Our results yield implications for prospective franchisees as well - only a fraction of franchisors make FPR and these tend to be higher quality franchisors. Thus, prospective franchisees should consider whether a franchisor makes an FPR when deciding whether to become a franchisee of a chain.

This study also has public policy implications for voluntary information disclosure in franchising. FPR requirements and enforcement have been the subject of debate in the US among the Federal Trade Commission (FTC), the Small Business Administration's Office of Advocacy,

\footnotetext{
${ }^{10}$ Given the results in our replication model, it can be claimed that the differences between the findings in our enhanced model and those in Michael (2009) are not because of the data used but on account of the augmentation of antecedents included and the amended operationalization of constructs in our enhanced model.
} 
NASAA, the American Bar Association (ABA), the International Franchise Association (IFA), and members of Congress (Price, 2000). Our findings reveal strong support for the quality signaling rationale for making an FPR - high quality franchisors are more likely to make an FPR than a low quality franchisor. Thus, the informational value of voluntary FPRs may reduce the benefits of making such disclosures mandatory. In other words, for prospective franchisees, there is no quality signaling value in a mandatory FPR while they can infer underlying franchisor quality when making an FPR is voluntary.

\subsection{Limitations and Future Research}

In this study, we empirically examined signaling behavior (in the form of voluntary information disclosure) in a business to business, entrepreneurial network context - these contexts have rarely been the subject of such investigations. However, our empirical analyses are limited to franchising data - therefore, further research may be needed to test our hypotheses in other entrepreneurship and SME contexts. We use the provision of FPR as our dependent variable, in the form of a dichotomous variable. Although the provision of FPR is not mandatory, it is regulated by FTC franchise rules and UFOC Item 19 guidelines. Recent research by Benoliel (2016) shows variation, across franchisors, in the information that is provided in their respective FPRs. Since this research only considers whether a franchisor provides or does not provide an FPR, future research could evaluate antecedents of the variation in the content of FPRs across franchisors. ${ }^{11}$

\footnotetext{
${ }^{11}$ We thank an anonymous reviewer for this insight.
} 


\section{REFERENCES}

Akerlof, G. (1970). The market for lemons: Quality uncertainty and the market mechanism. Quarterly Journal of Economics, 84(3), 488-500.

Aldrich, H., \& Auster, E. R. (1986). Even dwarfs started small: Liabilities of age and size and their strategic implications. In B. M. Staw \& L. L. Cummings (Eds.), Research in organizational behavior (Vol. 8, pp. 165-186). Greenwich, CT: JAI Press.

Antia, K. D., Zheng, X., \& Frazier, G. L. (2013). Conflict Management and Outcomes in Franchise Relationships: The Role of Regulation. Journal of Marketing Research, 50(5), 577-589. doi:10.1509/jmr.11.0144

Armstrong, J., Brodie, R., \& Parsons, A. (2001). Hypotheses in Marketing Science: Literature Review and Publication Audit. Marketing Letters, 12(2), 171-187. doi:10.1023/A:1011169104290

Arthurs, J. D., Busenitz, L. W., Hoskisson, R. E., \& Johnson, R. A. (2009). Signaling and initial public offerings: The use and impact of the lockup period. Journal of Business Venturing, 24(4), 360-372. doi:10.1016/j.jbusvent.2008.02.004

Asoni, A., \& Sanandaji, T. (2016). Identifying the effect of college education on business and employment survival. Small Business Economics, 46(2), 311-324. doi:10.1007/s11187015-9686-5

Backes-Gellner, U., \& Werner, A. (2007). Entrepreneurial Signaling via Education: A Success Factor in Innovative Start-Ups. Small Business Economics, 29(1), 173-190. doi:10.1007/s11187-006-0016-9

Bagwell, K., \& Riordan, M. H. (1991). High and Declining Prices Signal Product Quality. American Economic Review, 81(1), 224-239.

Baltagi, B. (2008). Econometric Analysis of Panel Data: John Wiley \& Sons.

Barthélemy, J. (2008). Opportunism, knowledge, and the performance of franchise chains. Strategic Management Journal, 29(13), 1451-1463. doi:10.1002/smj.719

Bates, T. (1995). A Comparison of Franchise and Independent Small Business Survival Rates. Small Business Economics, 7(5), 377-388.

Benoliel, U. (2016). Are Disclosures Really Standardized? The Case of Quick Service Restaurant Franchises Paper presented at the The 30th Annual International Society of Franchising Conference Groningen, The Netherlands.

Blair, R. D., \& Lafontaine, F. (2005). The Economics of Franchising. New York: Cambridge University Press.

Brickley, J. A., Misra, S., \& Van Horn, R. L. (2006). Contract Duration: Evidence from Franchising. Journal of Law and Economics, 49(1), 173-196. doi:10.1086/501081

Calderon-Monge, E., \& Huerta-Zavala, P. (2014). Brand and performance signals in the choice of franchise opportunities. The Service Industries Journal, 34(9-10), 772-787. doi:10.1080/02642069.2014.905920

Certo, S. T., Daily, C. M., \& Dalton, D. R. (2001). Signaling firm value through board structure: An investigation of initial public offerings. Entrepreneurship Theory and Practice, 26(2), 33-50.

Chamberlin, T. C. (1897). Studies for Students: The Method of Multiple Working Hypotheses. The Journal of Geology, 5(8), 837-848. doi:10.2307/30054868

Cheong, I., \& Kim, J. Y. (2004). Costly information disclosure in oligopoly. The Journal of Industrial Economics, 52(1), 121-132. doi:10.1111/j.0022-1821.2004.00218.x 
Chow, C. W., \& Wong-Boren, A. (1987). Voluntary Financial Disclosure by Mexican Corporations. The Accounting Review, 62(3), 533-541.

Chung, W., \& Kalnins, A. (2001). Agglomeration effects and performance: A test of the Texas lodging industry. Strategic Management Journal, 22(10), 969-988. doi:10.1002/smj.178

Clarkin, J. E., \& Rosa, P. J. (2005). Entrepreneurial teams within franchise firms. International Small Business Journal, 23(3), 303-334. doi:10.1177/0266242605052075

Combs, J. G., Michael, S. C., \& Castrogiovanni, G. J. (2009). Institutional influences on the choice of organizational form: the case of franchising. Journal of Management. doi:10.1177/0149206309336883

Connelly, B. L., Certo, S. T., Ireland, R. D., \& Reutzel, C. R. (2011). Signaling theory: A review and assessment. Journal of Management, 37(1), 39-67. doi:10.1177/0149206310388419

Crocker, K. J., \& Masten, S. E. (1988). Mitigating Contractual Hazards: Unilateral Options and Contract Length. The RAND Journal of Economics, 19(3), 327-343. doi:10.2307/2555660

Diamond, D. W. (1985). Optimal Release of Information By Firms. The Journal of Finance, 40(4), 1071-1094. doi:10.2307/2328395

Dye, R. A. (1985). Strategic accounting choice and the effects of alternative financial reporting requirements. Journal of accounting research, 23(2), 544-574. doi:10.2307/2490826

Fadairo, M., \& Lanchimba, C. (2013). Signaling the quality of a business concept; Evidence from a structural equations model with Brazilian data. Paper presented at the 40th Annual Conference of the European Association for Research in Industrial Economics.

Filatotchev, I., \& Bishop, K. (2002). Board Composition, Share Onership, and'Underpricing' of U.K. IPO Firms. Strategic Management Journal, 23(10), 941-955. doi:10.1002/smj.269

Gallini, N. T., \& Lutz, N. A. (1992). Dual distribution and royalty fees in franchising. Journal of Law, Economics, \& Organization, 471-501.

Gao, H., Darroch, J., Mather, D., \& MacGregor, A. (2008). Signaling Corporate Strategy in IPO Communication A Study of Biotechnology IPOs on the NASDAQ. Journal of Business Communication, 45(1), 3-30. doi:10.1177/0021943607309349

Gillis, W. E., Combs, J. G., \& Ketchen, D. J. (2014). Using Resource-Based Theory to Help Explain Plural Form Franchising. Entrepreneurship Theory and Practice, 38(3), 449-472. doi:10.1111/etap.12008

Golan, A., Judge, G., \& Perloff, J. M. (1996). Estimating the size distribution of firms using government summary statistics. The Journal of Industrial Economics, 69-80. doi: $10.2307 / 2950561$

Gonzalez-Diaz, M., \& Solis-Rodriguez, V. (2012). Why do entrepreneurs use franchising as a financial tool? An agency explanation. Journal of Business Venturing, 27(3), 325-341. doi:10.1016/j.jbusvent.2011.03.001

Grossman, S. J. (1981). The informational role of warranties and private disclosure about product quality. Journal of law and economics, 461-483.

Grünhagen, M., \& Dorsch, M. J. (2003). Does the Franchisor Provide Value to Franchisees? Past, Current, and Future Value Assessments of Two Franchisee Types. Journal of Small Business Management, 41(4), 366-384. doi:10.1111/1540-627X.00088

Guilloux, V., Gauzente, C., Kalika, M., \& Dubost, N. (2004). How France's Potential Franchisees Reach Their Decisions: A Comparison with Franchisers' Perceptions. Journal of Small Business Management, 42(2), 218-224. doi:10.1111/j.1540627X.2004.00107.x 
Hayes, A. F., \& Krippendorff, K. (2007). Answering the Call for a Standard Reliability Measure for Coding Data. Communication Methods and Measures, 1(1), 77-89. doi:10.1080/19312450709336664

Hendrikse, G., Hippmann, P., \& Windsperger, J. (2015). Trust, Transaction Costs and Contractual Incompleteness in Franchising. Small Business Economics, 44(4), 867-888. doi:10.1007/s11187-014-9626-9

Hendrikse, G., \& Windsperger, J. (2011). Determinants of contractual completeness in franchising. In M. Tuunanen, G. Cliquet, G. Hendrikse, J. Windsperger, (Ed.), New Developments in the Theory of Networks (pp. 13-30). Heidelberg: Physica-Verlag.

Hershman, S., \& Mazero, J. G. (2008). Financial Performance Representations: The New and Updated Earnings Claims (1 ed.). Illinois: American Bar Association.

Honig, B., Lampel, J., Siegel, D., \& Drnevich, P. (2014). Ethics in the Production and Dissemination of Management Research: Institutional Failure or Individual Fallibility? Journal of Management Studies, 51(1), 118-142. doi:10.1111/joms.12056

Hsiao, C. (2014). Analysis of Panel Data (3rd ed.). New York: Cambridge university press.

Hsieh, C., Lazzarini, S. G., Nickerson, J. A., \& Laurini, M. (2010). Does Ownership Affect the Variability of the Production Process? Evidence from International Courier Services. Organization Science, 21(4), 892-912. doi:10.1287/orsc.1090.0482

Hubbard, R., Vetter, D. E., \& Little, E. L. (1998). Replication in strategic management: Scientific testing for validity, generalizability, and usefulness. Strategic management journal, 19(3), 243-254. doi:10.1002/(SICI)1097-0266(199803)19:3\&lt;243::AIDSMJ951\&gt;3.0.CO;2-0

IHS-Economics. (2016). Franchise Business Economic Outlook for 2016: International Franchise Association Educational Foundation

Janney, J. J., \& Folta, T. B. (2006). Moderating effects of investor experience on the signaling value of private equity placements. Journal of Business Venturing, 21(1), 27-44. doi:10.1016/j.jbusvent.2005.02.008

Justis, R. T., \& Chan, P. S. (1991). Training for franchise management. Journal of Small Business Management, 29(3), 87.

Kacker, M., Dant, R. P., Emerson, J., \& Coughlan, A. T. (2016). How Firm Strategies Impact Size of Partner-Based Retail Networks: Evidence from Franchising. Journal of Small Business Management, 54(2), 506-531. doi:10.1111/jsbm.12155

Kacker, M., \& Wu, R. (2013). Specific Investments in Franchisor-Franchisee Relationships: A Model. Journal of Marketing Channels, 20(1-2), 120-140. doi:10.1080/1046669X.2013.747863

Kaufmann, D. (1995). The case against mandatory earnings claim disclosure. Franchise Law Journal, 15(1), 3.

Kaufmann, P. J., \& Dant, R. P. (2001). The pricing of franchise rights. Journal of Retailing, 77(4), 537-545. doi:10.1016/S0022-4359(01)00053-7

Keasey, K., Short, H., \& McGuinness, P. (1992). New issues on the U.K. Unlisted Securities Market: The ability of entrepreneurs to signal firm value. Small Business Economics, 4(1), 15-27. doi:10.1007/bf00402212

Kirmani, A., \& Rao, A. R. (2000). No Pain, No Gain: A Critical Review of the Literature on Signaling Unobservable Product Quality. Journal of Marketing, 64(2), 66-79. doi:10.1509/jmkg.64.2.66.18000 
Kosová, R., \& Lafontaine, F. (2010). Survival and Growth in Retail and Service Industries: Evidence from Franchised Chains. The Journal of Industrial Economics, 58(3), 542-578. doi:10.1111/j.1467-6451.2010.00431.x

Kwoka, J. E. (1979). The effect of market share distribution on industry performance. The Review of Economics and Statistics, 101-109. doi:10.2307/1924836

Lafontaine, F. (1992). Agency theory and franchising: some empirical results. The RAND Journal of Economics, 23(2), 263-283. doi:10.2307/2555988

Lafontaine, F. (1993). Contractual arrangements as signaling devices: evidence from franchising. Journal of Law, Economics, \& Organization, 256-289.

Lafontaine, F., \& Blair, R. D. (2009). The Evolution of Franchising and Franchise Contracts: Evidence from the United States. Entrepreneurial Business Law Journal, 3(2), 381-434.

Lafontaine, F., \& Shaw, K. L. (1998). Franchising growth and franchisor entry and exit in the US market: myth and reality. Journal of Business Venturing, 13(2), 95-112. doi:10.1016/S0883-9026(97)00065-7

Lafontaine, F., \& Shaw, K. L. (1999). The dynamics of franchise contracting: Evidence from panel data. Journal of Political Economy, 107(5), 1041-1080. doi:10.3386/w5585

Lafontaine, F., \& Shaw, K. L. (2005). Targeting managerial control: evidence from franchising. RAND Journal of Economics, 36(1), 131-150. doi:10.2307/1593758

Lardon, A., \& Deloof, M. (2014). Financial disclosure by SMEs listed on a semi-regulated market: evidence from the Euronext Free Market. Small Business Economics, 42(2), 361385. doi:10.1007/s11187-013-9484-X

Lee, P. M. (2001). What's in a name. com?: The effects of '. com'name changes on stock prices and trading activity. Strategic Management Journal, 22(8), 793-804. doi:10.1002/smj.177

Leland, H. E., \& Pyle, D. H. (1977). Informational asymmetries, financial structure, and financial intermediation. The journal of Finance, 32(2), 371-387. doi:10.2307/2326770

Luangsuvimol, T., \& Kleiner, B. H. (2004). Effective franchise management. Management Research News, 27(4/5), 63-71. doi:10.1108/01409170410784482

Lucia-Palacios, L., Bordonaba-Juste, V., Madanoglu, M., \& Alon, I. (2014). Franchising and value signaling. Journal of Services Marketing, 28(2), 105-115. doi:10.1108/JSM-092013-0253

López-Bayón, S., \& González-Díaz, M. (2010). Indefinite contract duration: Evidence from electronics subcontracting. International Review of Law and Economics, 30(2), 145-159. doi:10.1016/j.irle.2010.03.001

Michael, S. (2014). Can franchising be an economic development strategy? An empirical investigation. Small Business Economics, 42(3), 611-620. doi:10.1007/s11187-013-95001

Michael, S. C. (1999). The Elasticity of Franchising. Small Business Economics, 12(4), 313-320. doi:10.1023/A:1008019418231

Michael, S. C. (2000). The effect of organizational form on quality: the case of franchising. Journal of Economic Behavior \&amp; Organization, 43(3), 295-318. doi:10.1016/S01672681(00)00125-6

Michael, S. C. (2003). First mover advantage through franchising. Journal of business venturing, 18(1), 61-80. doi:10.1016/S0883-9026(01)00085-4

Michael, S. C. (2009). Entrepreneurial Signaling to Attract Resources: The Case of Franchising. Managerial and Decision Economics, 30(6), 405-422. doi:10.1002/mde.1460 
Milgrom, P. (1981). Good news and bad news: Representation theorems and applications. The Bell Journal of Economics, 12(2), 380-391. doi:10.2307/3003562

Milgrom, P., \& Roberts, J. (1986). Price and advertising signals of product quality. Journal of Political Economy, 94(4), 796-821. doi:10.1086/261408

Mishra, D. P., Heide, J. B., \& Cort, S. G. (1998). Information asymmetry and levels of agency relationships. Journal of marketing Research, 35(3), 277-295. doi:10.2307/3152028

Mitsuhashi, H., Shane, S., \& Sine, W. D. (2008). Organization governance form in franchising: efficient contracting or organizational momentum? Strategic Management Journal, 29(10), 1127-1136. doi:10.1002/smj.702

Montiel, I., Husted, B. W., \& Christmann, P. (2012). Using private management standard certification to reduce information asymmetries in corrupt environments. Strategic Management Journal, 33(9), 1103-1113. doi:10.1002/smj.1957

Nelson, P. (1970). Information and Consumer Behavior. Journal of Political Economy, 78(2), 311-329. doi:10.1086/259630

Perrigot, R. (2006). Services vs retail chains: are there any differences? International Journal of Retail \& Distribution Management, 34(12), 918-930. doi:10.1108/09590550610714648

Platt, J. R. (1964). Strong Inference: Certain Systematic Methods of Scientific Thinking May Produce Much More Rapid Progress than others. Science(146), 347-353.

Price, R. (2000). Who reports earnings when reporting is optional? The market for new franchises. Journal of Accounting and Economics, 28(3), 391-423. doi:10.1016/S01654101(00)00009-4

Riley, J. G. (1975). Competitive Signaling. Journal of Economic Theory, 10(2), 174-186. doi:10.1016/0022-0531(75)90049-6

Rostamkalaei, A., \& Freel, M. (2016). The cost of growth: small firms and the pricing of bank loans. Small Business Economics, 46(2), 255-272. doi:10.1007/s11187-015-9681-X

Sen, K. C. (1993). The use of initial fees and royalties in business-format franchising. Managerial and decision Economics, 14(2), 175-190. doi:10.1002/mde.4090140209

Seshadri, S. (2002). Outlet ownership in franchising systems: an agency based approach. Managerial and Decision Economics, 23(6), 355-369. doi:10.1002/mde.1073

Shane, S. (1998). Research notes and communications: Making new franchise systems work. Strategic Management Journal, 19(7), 697-707. doi:10.1002/(SICI)10970266(199807)19:7\&lt;697::AID-SMJ972\&gt;3.0.CO;2-O

Shane, S., Shankar, V., \& Aravindakshan, A. (2006). The Effects of New Franchisor Partnering Strategies on Franchise System Size. Management Science, 52(5), 773-787. doi: $10.1287 / \mathrm{mnsc} .1050 .0449$

Sorenson, O., \& Sorensen, J. B. (2001). Finding The Right Mix: Franchising, Organizational Learning, And Chain Performance. Strategic Management Journal, 22(6/7), 713-724. doi:10.1002/smj.185

Spence, M. (1973). Job market signaling. The quarterly journal of Economics, 87 (3), 355-374.

Spence, M. (2002). Signaling in retrospect and the informational structure of markets. American Economic Review, 92(3), 434-459. doi:10.1257/00028280260136200

Srinivasan, R., \& Sihi, D. (2012). Marketing Information Disclosures: A Review and Research Agenda. In S. Ganesan (Ed.), Handbook of Marketing and Finance (pp. 108-126). UK: Edward Edgar Publishing Limited. 
Stanworth, J., \& Kaufmann, P. (1996). Similarities and differences in UK and US franchise research data: towards a dynamic model of franchisee motivation. International Small Business Journal, 14(3), 57-70. doi:10.1177/0266242696143003

Strotmann, H. (2007). Entrepreneurial Survival. Small Business Economics, 28(1), 87-104. doi:10.1007/s11187-005-8859-Z

Stump, R. L., \& Heide, J. B. (1996). Controlling supplier opportunism in industrial relationships. Journal of Marketing Research, 33(4), 431-441. doi:10.2307/3152214

Terlaak, A. (2007). Order without Law? The Role of Certified Management Standards in Shaping Socially Desired Firm Behaviors. The Academy of Management Review, 32(3), 968-985. doi:10.2307/20159344

Tsang, E. W. K., \& Kwan, K.-M. (1999). Replication and Theory Development in Organizational Science: A Critical Realist Perspective. The Academy of Management Review, 24(4), 759-780. doi:10.2307/259353

Verrecchia, R. E. (1983). Discretionary Disclosure. Journal of accounting and economics, 5, 179-194. doi:10.1016/0165-4101(83)90011-3

Wathne, K. H., \& Heide, J. B. (2000). Opportunism in Interfirm Relationships: Forms, Outcomes, and Solutions. Journal of Marketing, 64(4), 36-51. doi:10.1509/jmkg.64.4.36.18070

Williams, D. R., Duncan, W. J., \& Ginter, P. M. (2010). Testing a model of signals in the IPO offer process. Small Business Economics, 34(4), 445-463. doi:10.1007/s11187-008-91301

Windsperger, J. (2001). The fee structure in franchising: a property rights view. Economics Letters, 73(2), 219-226. doi:10.1016/S0165-1765(01)00491-8 
Table 1: Constructs, Variables and Operationalizations

\begin{tabular}{|c|c|c|}
\hline $\begin{array}{l}\text { Construct/ } \\
\text { Factor }\end{array}$ & Variable & Operationalization \\
\hline $\begin{array}{l}\text { Information } \\
\text { Disclosure }\end{array}$ & Provision of FPR & $\begin{array}{l}\text { Binary variable with value of one if the franchisor provides an FPR and } \\
\text { zero otherwise. }\end{array}$ \\
\hline \multirow{5}{*}{ Quality } & Ongoing fees & $\begin{array}{l}\text { Sum of the Royalty Rate and Advertising Fee. Both of them are expressed } \\
\text { as a percentage of sales and are paid by a franchisee to the franchisor on } \\
\text { an ongoing basis. }\end{array}$ \\
\hline & $\begin{array}{l}\text { Commitment to } \\
\text { Industry Standards }\end{array}$ & $\begin{array}{l}\text { Dummy variable with value of one if the firm is member of IFA and zero } \\
\text { otherwise. }\end{array}$ \\
\hline & Complexity & $\begin{array}{l}\text { Counting the number of supporting services provided by the franchisor to } \\
\text { franchisees: } \\
\begin{array}{ll}\text { - Central Data Processing } & \text { - Inventory Control } \\
\text { - Central Purchasing } & \text { - Franchisee Newsletter } \\
\text { - Field Operations Evaluation } & \text { - Regional or National Meetings } \\
\text { - Field Training } & \text { - } 800 \text { Telephone Hotline } \\
\text { - Initial Store Opening } & \\
\text { (Source: Kacker et al., 2016; Shane, 1998) }\end{array}\end{array}$ \\
\hline & $\begin{array}{l}\text { Log Concept } \\
\text { Development Time }\end{array}$ & $\begin{array}{l}\text { Natural logarithm of the number of years between business establishment } \\
\text { and first franchise sale. (Source: Kacker et al., 2016; Lafontaine \& Shaw, } \\
\text { 1998) }\end{array}$ \\
\hline & $\begin{array}{l}\text { Fraction of } \\
\text { Ownership }\end{array}$ & Percent of outlets owned by the franchisor. \\
\hline \multirow{2}{*}{$\begin{array}{l}\text { Partner } \\
\text { Qualification }\end{array}$} & Log Min Net Worth & $\begin{array}{l}\text { Natural logarithm of the minimum net worth (in USD thousands) that the } \\
\text { potential franchisee should have. }\end{array}$ \\
\hline & $\begin{array}{l}\text { Log Initial } \\
\text { Investment }\end{array}$ & $\begin{array}{l}\text { Natural logarithm of the initial franchise fee (in USD thousands) required } \\
\text { from franchisees by the franchisor. }\end{array}$ \\
\hline Cost & Log total units & $\begin{array}{l}\text { Natural logarithm of total number of units in the chain including } \\
\text { franchised and owned units. Considering ex-ante cost of gathering and } \\
\text { processing the data and ex-post cost of potential litigations, we assumed } \\
\text { that larger chains are more likely to afford the costs. We used logarithm } \\
\text { as we expect this relative cost declines when chains get larger, at a } \\
\text { decreasing rate. }\end{array}$ \\
\hline \multirow{2}{*}{ Competition } & Market Share & $\begin{array}{l}\text { The proportion of all outlets in the industry category which associated } \\
\text { with the franchisor. }\end{array}$ \\
\hline & $\begin{array}{l}\text { Two Firm } \\
\text { Concentration }\end{array}$ & $\begin{array}{l}\text { The proportion of all outlets in the industry category which associated } \\
\text { with the two biggest chains in the industry. }\end{array}$ \\
\hline $\begin{array}{l}\text { Information } \\
\text { Asymmetry }\end{array}$ & $\begin{array}{l}\text { Degree of } \\
\text { Information } \\
\text { Asymmetry }\end{array}$ & $\begin{array}{l}\text { Two dummy variables which are one if the franchisor agrees with having } \\
\text { additional outlets for the same franchisee or conversion and zero } \\
\text { otherwise. }\end{array}$ \\
\hline \multirow{2}{*}{$\begin{array}{l}\text { Institutional } \\
\text { Isomorphism }\end{array}$} & $\begin{array}{l}\text { Does the market } \\
\text { leader provide FPR? }\end{array}$ & $\begin{array}{l}\text { Dummy variable with value of one if the market leader makes FPR and } \\
\text { zero if not. }\end{array}$ \\
\hline & $\begin{array}{l}\text { Log number of } \\
\text { competitors who } \\
\text { make FPR. }\end{array}$ & $\begin{array}{l}\text { Natural logarithm of the number of other franchisors within the sector } \\
\text { that provide FPR. }\end{array}$ \\
\hline $\begin{array}{l}\text { Environmental } \\
\text { Uncertainty }\end{array}$ & Contract Duration & Average duration of the contract between franchisor and franchisees. \\
\hline
\end{tabular}


Table 2: Descriptive Statistics and Correlations for Replication of Michael (2009) Model

\begin{tabular}{|c|c|c|c|c|c|c|c|c|c|c|c|c|c|c|c|}
\hline No & Variable & $\begin{array}{l}\text { \# of } \\
\text { Obs. }\end{array}$ & Mean & $\begin{array}{l}\text { Std. } \\
\text { Dev. }\end{array}$ & Min & Max & 1 & 2 & 3 & 4 & 5 & 6 & 7 & 8 & 9 \\
\hline 1 & Does firm claim? & 8,056 & 0.30 & 0.460 & 0.00 & 1.00 & 1.00 & & & & & & & & \\
\hline 2 & Log of owned units & 5,605 & 1.93 & 1.839 & 0.00 & 9.03 & 0.13 & 1.00 & & & & & & & \\
\hline 3 & Royalty & 7,917 & 5.13 & 3.279 & 0.00 & 40.0 & -0.01 & 0.00 & 1.00 & & & & & & \\
\hline 4 & Percent owned & 8,128 & 15.36 & 24.01 & 0.00 & 100 & 0.03 & 0.37 & -0.01 & 1.00 & & & & & \\
\hline 5 & Market Share & 8,130 & 0.05 & 0.104 & 0.00 & 0.96 & 0.04 & 0.32 & -0.01 & -0.11 & 1.00 & & & & \\
\hline 6 & Two-firm concentration & 8,150 & 0.51 & 0.216 & 0.17 & 1.48 & 0.00 & -0.01 & -0.02 & -0.02 & 0.17 & 1.00 & & & \\
\hline 7 & $\begin{array}{l}\text { Does market leader } \\
\text { claim? }\end{array}$ & 8,150 & 0.38 & 0.485 & 0.00 & 1.00 & 0.04 & 0.02 & 0.06 & 0.04 & 0.01 & -0.01 & 1.00 & & \\
\hline 8 & $\begin{array}{l}\text { Log of percent who } \\
\text { claim. }\end{array}$ & 7,970 & -1.32 & 0.507 & -3.17 & 1.47 & 0.09 & 0.15 & -0.08 & 0.06 & 0.03 & 0.00 & 0.13 & 1.00 & \\
\hline 9 & $\begin{array}{l}\text { Log of number of } \\
\text { competitors who claim }\end{array}$ & 7,970 & 2.24 & 1.020 & 0.00 & 5.49 & 0.02 & 0.16 & -0.03 & 0.02 & -0.27 & -0.22 & -0.06 & 0.52 & 1.00 \\
\hline
\end{tabular}

Table 3: Michael (2009) Model Replication - Probit Estimation Results from Pooled Panel

\begin{tabular}{|c|c|c|c|c|c|}
\hline & $\mathrm{H} 1$ & $\mathrm{H} 2$ & $\mathrm{H} 3$ & $\mathrm{H} 4$ & $\mathrm{H} 5$ \\
\hline Log of owned units & $\begin{array}{l}0.0801 * * * \\
(0.0094)\end{array}$ & $\begin{array}{l}.0892 * * * \\
(.0095)\end{array}$ & $\begin{array}{l}.0862 * * * \\
(.0102)\end{array}$ & $\begin{array}{l}.0853 * * * \\
(.0100)\end{array}$ & $\begin{array}{l}.0801 * * * \\
(.0094)\end{array}$ \\
\hline Royalty & & $\begin{array}{l}-.0016 \\
(.0057)\end{array}$ & & & \\
\hline Percent owned & & & $\begin{array}{l}-0.0011 \\
(.0007)\end{array}$ & & \\
\hline Market Share & & & & $\begin{array}{l}-0.2559 \\
(.1751)\end{array}$ & \\
\hline Two-firm concentration & & & & & $\begin{array}{l}0.0036 \\
(0.0780)\end{array}$ \\
\hline Log likelihood & -3486.3 & -3380.5 & -3485.1 & -3485.2 & -3486.3 \\
\hline Chi-squared test & $72.40 * * *$ & $86.90 * * *$ & $74.71 * * *$ & $74.55 * * *$ & $72.40 * * *$ \\
\hline Degree of freedom & 1 & 2 & 2 & 2 & 2 \\
\hline
\end{tabular}


Table 4: Descriptive Statistics for Expanded Model

\begin{tabular}{|c|c|c|c|c|c|c|}
\hline No & Variable & $\begin{array}{c}\text { No. of } \\
\text { Observatio } \\
\text { ns }\end{array}$ & Mean & $\begin{array}{l}\text { Std. } \\
\text { Dev. }\end{array}$ & Min & Max \\
\hline 1 & Provision of FPR & 8,056 & 0.303 & 0.460 & 0.000 & 1.000 \\
\hline 2 & Ongoing Fees & 6,032 & 6.718 & 3.791 & 0.000 & 40.00 \\
\hline 3 & $\begin{array}{l}\text { Commitment to Industry } \\
\text { Standard }\end{array}$ & 5,697 & 0.514 & 0.500 & 0.000 & 1.000 \\
\hline 4 & Complexity & 8,152 & 6.585 & 1.762 & 0.000 & 11.000 \\
\hline 5 & Concept Development Time & 6,869 & 1.607 & 1.130 & 0.000 & 4.860 \\
\hline 6 & Percent unit owned & 6,395 & 14.643 & 23.021 & 0.000 & 100.0 \\
\hline 7 & Log Min Net Worth & 6,122 & 5.074 & 1.143 & 0.000 & 9.616 \\
\hline 8 & Log Franchise Fee & 6,172 & 3.061 & 0.642 & -0.357 & 6.022 \\
\hline 9 & Log Total Units & 8,130 & 4.453 & 1.719 & 0.000 & 10.40 \\
\hline 10 & Two Firm Concentration & 8,150 & 0.495 & 0.174 & 0.186 & 1.000 \\
\hline 11 & Market Share & 8,130 & 0.046 & 0.104 & 0.000 & 0.963 \\
\hline 12 & Additional Unit Agreement & 8,044 & 0.847 & 0.360 & 0.000 & 1.000 \\
\hline 13 & Conversion & 7,449 & 0.640 & 0.480 & 0.000 & 1.000 \\
\hline 14 & Market Leader FPR & 8,150 & 0.379 & 0.485 & 0.000 & 1.000 \\
\hline 15 & $\begin{array}{l}\text { Log No. of competitor with } \\
\text { FPR }\end{array}$ & 7,970 & 2.240 & 1.001 & 0.000 & 3.850 \\
\hline 16 & Contract Duration & 7,877 & 11.128 & 5.120 & 0.000 & 40.00 \\
\hline
\end{tabular}


Table 5: Correlations for Expanded Model

\begin{tabular}{|c|c|c|c|c|c|c|c|c|c|c|c|c|c|c|c|c|c|}
\hline No & Variable & 1 & 2 & 3 & 4 & 5 & 6 & 7 & 8 & 9 & 10 & 11 & 12 & 13 & 14 & 15 & 16 \\
\hline 1 & Provision of FPR & 1.00 & & & & & & & & & & & & & & & \\
\hline 2 & Ongoing Fees & 0.09 & 1.00 & & & & & & & & & & & & & & \\
\hline 3 & $\begin{array}{l}\text { Commitment to } \\
\text { Industry Standard }\end{array}$ & 0.20 & 0.10 & 1.00 & & & & & & & & & & & & & \\
\hline 4 & Complexity & 0.10 & 0.10 & 0.09 & 1.00 & & & & & & & & & & & & \\
\hline 5 & $\begin{array}{l}\text { Concept Development } \\
\text { Time }\end{array}$ & 0.07 & -0.06 & 0.05 & 0.02 & 1.00 & & & & & & & & & & & \\
\hline 6 & Percent unit owned & 0.07 & 0.02 & -0.06 & -0.03 & 0.25 & 1.00 & & & & & & & & & & \\
\hline 7 & Log Min Net Worth & 0.18 & 0.09 & 0.22 & 0.13 & 0.11 & 0.26 & 1.00 & & & & & & & & & \\
\hline 8 & Log Franchise Fee & 0.12 & 0.13 & 0.21 & 0.07 & 0.05 & 0.11 & 0.41 & 1.00 & & & & & & & & \\
\hline 9 & Log Total Units & 0.14 & 0.11 & 0.38 & 0.16 & -0.05 & -0.22 & 0.14 & 0.10 & 1.00 & & & & & & & \\
\hline 10 & $\begin{array}{l}\text { Two Firm } \\
\text { Concentration }\end{array}$ & 0.06 & -0.06 & 0.04 & 0.00 & -0.06 & -0.11 & -0.13 & -0.01 & 0.04 & 1.00 & & & & & & \\
\hline 11 & Market Share & 0.06 & -0.01 & 0.19 & 0.08 & 0.00 & -0.09 & -0.05 & 0.08 & 0.50 & 0.25 & 1.00 & & & & & \\
\hline 12 & $\begin{array}{l}\text { Additional Unit } \\
\text { Agreement }\end{array}$ & -0.08 & -0.06 & -0.05 & 0.02 & 0.05 & -0.03 & -0.04 & -0.09 & -0.03 & -0.04 & -0.06 & 1.00 & & & & \\
\hline 13 & Conversion & 0.00 & 0.02 & 0.02 & 0.09 & 0.05 & 0.03 & 0.05 & -0.06 & 0.08 & -0.13 & 0.00 & 0.08 & 1.00 & & & \\
\hline 14 & Market Leader FPR & 0.07 & 0.01 & 0.04 & -0.01 & -0.01 & -0.03 & -0.08 & 0.06 & 0.03 & 0.18 & 0.02 & -0.09 & -0.09 & 1.00 & & \\
\hline 15 & $\begin{array}{l}\text { Log No. of competitor } \\
\text { with FPR }\end{array}$ & -0.03 & 0.10 & -0.01 & 0.02 & 0.10 & 0.14 & 0.28 & 0.03 & 0.01 & -0.43 & -0.38 & 0.04 & 0.16 & -0.13 & 1.00 & \\
\hline 16 & Contract Duration & 0.05 & 0.10 & 0.09 & 0.07 & -0.02 & 0.07 & 0.31 & 0.16 & 0.24 & -0.13 & 0.03 & -0.02 & 0.05 & -0.11 & 0.22 & 1.00 \\
\hline
\end{tabular}


Table 6: Logit Estimation Results for Expanded Model (9 year panel data set)

\begin{tabular}{|c|c|c|c|c|c|c|}
\hline & & & Model 1 & & Model $2^{+}$ & \\
\hline Log likelihood & & & -1593.161 & & -1367.301 & \\
\hline Chi-squared test & & & $604.7 * * *$ & & $571.6 * * *$ & \\
\hline Degree of freedom & & & 61 & & 61 & \\
\hline Pseudo $\mathrm{R}^{2}$ & & & 0.1595 & & 0.1729 & \\
\hline Independent Variables & Hypothesis & $\begin{array}{l}\text { Hyp. effect } \\
\text { sign }\end{array}$ & Coeff. & $\begin{array}{c}\text { St. } \\
\text { Error }\end{array}$ & Coeff. & $\begin{array}{c}\text { St. } \\
\text { Error }\end{array}$ \\
\hline Ongoing Fees & $\mathrm{H} 1$ & $+/-$ & $0.051 * * *$ & 0.015 & $0.037 * *$ & 0.016 \\
\hline Commitment to Ind. Stan. & $\mathrm{H} 2$ & $+/-$ & $0.681 * * *$ & 0.101 & $0.705 * * *$ & 0.111 \\
\hline Complexity & $\mathrm{H} 3$ & $+/-$ & $0.074 * *$ & 0.029 & $0.070 * *$ & 0.033 \\
\hline CDT & $\mathrm{H} 4$ & $+/-$ & $0.146 * * *$ & 0.043 & $0.159 * * *$ & 0.047 \\
\hline Percent unit owned & H5 & $+/-$ & $0.005 * *$ & 0.002 & $0.006^{* *}$ & 0.003 \\
\hline Log Min Net Worth & H6 & + & $0.249 * * *$ & 0.058 & $0.302 * * *$ & 0.063 \\
\hline Log Franchise Fee & H6 & + & 0.070 & 0.102 & 0.021 & 0.112 \\
\hline \multicolumn{7}{|l|}{ Control Variables } \\
\hline Log Total Units & & & $0.126 * * *$ & 0.040 & $0.132 * *$ & 0.051 \\
\hline Two Firm Concentration & & & -0.564 & 0.491 & -0.320 & 0.522 \\
\hline Market Share & & & -1.032 & 0.678 & -1.131 & 0.751 \\
\hline Additional Unit Agreement & & & $-0.400 * * *$ & 0.125 & $-0.425 * * *$ & 0.136 \\
\hline Conversion & & & -0.107 & 0.098 & -0.120 & 0.106 \\
\hline Market Leader FPR & & & $0.549 * * *$ & 0.153 & $0.605^{* * *}$ & 0.167 \\
\hline Log competitor with FPR & & & $-2.939 * * *$ & 0.246 & $-3.129 * * *$ & 0.272 \\
\hline Contract Duration & & & -0.007 & 0.011 & -0.003 & 0.012 \\
\hline Constant & & & $4.935 * * *$ & 0.904 & $5.318 * * *$ & 1.013 \\
\hline No of Sig. Year dummies & & & 4 & & 6 & \\
\hline Year dummies joint Sig. & & & Yes $* * *$ & & Yes*** & \\
\hline No of Sig. Category dummies & & & 40 & & 41 & \\
\hline Category dummies joint Sig. & & & Yes $* * *$ & & Yes*** & \\
\hline
\end{tabular}

Notes: $* \mathrm{p}<.1 ; * * \mathrm{p}<.05 ; * * * \mathrm{p}<.01$

t Model 2 shows the results for only a sample of franchisors with more than 7 years of experience and 15 units

Table 7: Signal Classification Results

\begin{tabular}{|l|c|c|c|c|}
\hline \multirow{2}{*}{ Signal } & \multicolumn{2}{|c|}{ Default-Independent Signals } & \multicolumn{2}{c|}{ Default-Contingent Signals } \\
\hline & Sale-Independent & Sale-Contingent & Revenue-Risking & Cost-Risking \\
\hline FPR & & & & $\checkmark$ \\
\hline Ongoing Fees & & & & \\
\hline Commitment to Ind. Standard & $\checkmark$ & & & \\
\hline Complexity & & $\checkmark$ & & \\
\hline Concept Dev. Time & $\checkmark$ & & $\checkmark$ & \\
\hline Ownership Fraction & & & & \\
\hline
\end{tabular}

